\title{
SISTEM PEMBEBANAN PEMBUKTIAN TERBALIK PADA TINDAK PIDANA KORUPSI
}

\author{
Ardi Ferdian \\ Fakultas Hukum Universitas Brawijaya Malang \\ Email: ardi@ub.ac.id
}

\begin{abstract}
Burden of proof is part of proof law system. In the legal proof of corruption, there is reversed proof load system. Firstly, it concerns about the proof of the criminal acts. Yet, it is restricted to criminal bribery gratification worth 10 billion rupiahs or more [article12B(1a)]. Secondly, it concerns about the defendant's property that has not been indicted (article 38B). There are few benefits to prove criminal act in addition to those two objects. To prove corruption other than aforementioned, using regular system is imposed on prosecutors. It may cause problems in practice, the conflict between the evidentiary burden of proof results between the first and the second objects.
\end{abstract}

Keywords: corruption, law of evidence, the burden of proof

\begin{abstract}
Abstrak
Beban pembuktian adalah bagian dalam sistem hukum pembuktian. Hukum pembuktian tindak pidana korupsi mengenal system beban pembuktian terbalik. Pertama, mengenai pembuktian tindak pidananya. Namun terbatas pada tindak pidana menerima suap gratifikasi yang nilainya Rp 10 miliar atau lebih [Pasal 12B (1a)]. Kedua, mengenai harta benda terdakwa yang belum didakwakan (Pasal 38B). Tidak banyak manfaatnya untuk membuktikan tindak pidana selain kedua objek tersebut. Untuk membuktikan tindak pidana korupsi selain yang disebutlkan pertama, menggunakan sistem biasa ialah dibebankan pada jaksa. Dalam praktik dapat menimbulkan persoalan, yakni pertentangan antara hasil pembuktian beban pembuktian terbalik antara objek yang pertama dan yang kedua.
\end{abstract}

Kata kunci: tindak pidana korupsi, hukum pembuktian, beban pembuktian terbalik.

\section{Latar Belakang}

Sistem pembebanan pembuktian terbalik dalam hukum pidana korupsi Indonesia adalah diadopsi dari hukum pembuktian perkara korupsi dari negara anglo saxon seperti Inggris, Singapura dan Malaysia. Sistem pembebanan pembuktian terbalik hanya diterapkan pada tindak pidana yang berkenaan dengan gratification yang berhubungan dengan suap.

Banyak orang menganggap bahwa sistem pembuktian Tindak Pidana Korupsi dalam UU Nomor 31. tahun 1999 yang diubah dengan UU Nomor 20 tahun 2001 (selanjutnya disebut UUTPK) lebih baik, karena menganut sistem pembuktian terbalik. Dengan pemikiran bahwa sistem terbalik lebih mudah untuk membuktikan TPK yang didakwakan, sehingga secara otomatis lebih mudah pula untuk memberantas korupsi. Pendapat seperti itu ternyata tidak seluruhnya benar. Memang benar dalam UUTPK menganut sistem pembuktian terbalik, tetapi pertanyaan seperti apa yang dimaksud dengan sistem terbalik, bagaimana cara penerapannya, apa standar bukti yang digunakan dan sebagainya, pertanyaanpertanyaan seperti itu tidak mudah dijawab oleh setiap orang.

Terbukti dalam praktik dapat dilihat bahwa peran Jaksa Penuntut Umum, Penasehat Hukum atau Majelis Hakim dalam menjalankan fungsi pembuktian dari TPK yang didakwakan, tidak 
berbeda dengan proses dan prosedur pembuktian menurut KUHAP. Seolah-olah sistem pembuktian korupsi tidak berbeda dengan sistem biasa (KUHAP). Keadaan ini membuktikan bahwa sistem pembuktian terbalik maupun semi terbalik belum berperan dalam memberantas korupsi.

\section{Pembahasan}

\section{a. Sistem Beban Pembuktian Tindak Pidana Korupsi}

Regelement of Strafvordering (RSv) dan HIR (dulu) maupun KUHAP, begitu pula semuanya menganut sistem atau teori pembuktian berdasarkan Undang-undang secara negative (negatief wettelijk) yang dapat kita simpulkan berdasarkan Pasal 183 KUHAP. ${ }^{1}$ Standar bukti ${ }^{2}$ tersebut ialah (1) harus sekurang-kurangnya dua alat bukti yang sah, dan (2) dari alat bukti tersebut hakim mendapatkan keyakinan bahwa terdakwa bersalah telah melakukan tindak pidana. Dengan syarat itu, barulah hakim dapat menjatuhkan pidana.

Hukum pidana korupsi yang merupakan lex specialis, sehingga tentang pembuktian dibedakan 3 sistem beban pembuktian. Pertama sistem terbalik, kedua sistim biasa (seperti KUHAP), ketiga semi terbalik atau juga bisa disebut sistem berimbang terbalik.

\section{a.1. Sistem Terbalik}

Sistem terbalik terdapat dalam Pasal 37 jo 12B ayat (1) jo 38A dan 38B UUTPK. Dilihat dari sudut objek apa yang harus dibuktikan terdakwa, maka pembuktian terbalik ada 2 (dua) macam, ialah:

a. Pembuktian terbalik pada TPK suap menerima gratifikasi yang nilainya $\mathrm{Rp} 10$ juta atau lebih (pasal 12B ayat 1 jo 37 ayat 2 jo 38A);

b. Pembuktian terbalik pada harta benda terdakwa yang belum didakwakan (Pasal 38B).

Sistem beban terbalik ditujukan untuk membuktian dua hal saja.Oleh karena itu dapat disebut pembuktian terbalik yang terbatas. Pembuktian melalui beban pembuktian terbalik terbatas mempunyai tujuan yang pertama membuk- tikan bahwa benar ataukah tidak menerima suap gratifikasi. Kedua membuktian bahwa harta benda yang belum didakwakan mempunyai sumber yang haram ataukah halal.

\section{a.1.1. Pembuktian Terbalik dalam hal menerima gratifikasi (Ps 12B (1) jo 37 jo 38A)}

Pasal 37 menyatakan bahwa terdakwa berhak untuk membuktikan bahwa dirinya tidak melakukan tindak pidana korupsi (ayat 1); dalam hal terdakwa dapat membuktikan bahwa ia tidak melakukan tindak pidana korupsi, maka pembuktian tersebut digunakan oleh pengadilan sebagai dasar untuk menyatakan bahwa dakwaan tidak terbukti (ayat 2).

Ketentuan ayat (2) merupakan inti sistem beban pembuktian terbalik tindak pidana korupsi. Pasal 37 berhubungan dengan Pasal 12B dan Pasal 37A ayat (3). Hubungannya dengan Pasal 12B, ialah bahwa sistem beban pembuktian terbalik pada Pasal 37 berlaku pada TPK menerima suap gratifikasi yang nilainya $\mathrm{Rp} 10$ juta atau lebih [Pasal 12B ayat (1) huruf a]. Sementara itu hubungannya dengan Pasal 37A khususnya ayat (3), bahwa sistem terbalik menurut Pasal 37 berlaku dalam hal pembuktian tentang sumber (asal) harta benda terdakwa dan lain-lain, diluar perkara pokok pasal-pasal yang disebutkan dalam Pasal 37A, dalam hal ini hanya TPK suap menerima gratifikasi yang tidak disebut dalam pasal 37A ayat (3).

Isi rumusan Pasal 12B ayat (1) UUTPK mengandung 4 arti yang dapat dijelaskan sebagai berikut:

1. Norma huruf a berhubungan erat dengan (dijelaskan oleh) Pasal 37. Artinya ialah tentang apa yang dimaksud beban pembuktian menurut norma ayat (1) huruf a dalam hal ini ada pada terdakwa dan penerapannya dirumuskan pada Pasal 37.

2. Sistem terbalik berlaku pada TPK suap menerima gratifikasi yang nilainya Rp 10 juta atau lebih.

3. Sedangkan TPK suap menerima gratifikasi yang nilainya kurang dari Rp 10 juta, beban

1 Andi Hamzah, Hukum Acara Pidana Indonesia, Penerbit Sinar Grafika, Jakarta, 2001, hlm. 250.

2 Penyebutan standar bukti digunakan oleh Adami Chazawi. Lihat Adami Chazawi (I), Hukum Pembuktian Tindak Pidana Korupsi, Penerbit Bayumedia Publishing, Malang, 2011, hlm. 23. 
pembuktian ada pada JPU. Artinya dengan sistem biasa sesuai KUHAP.

4. Mengenai unsur-unsur tindak pidana menerima suap gratifikasi, ialah: (1) subjek hukumnya adalah pegawai negeri atau penyelenggara negara; (2) perbuatannya menerima gratifikasi; (3) berhubungan dengan jabatannya; dan (4) berlawanan dengan kewajiban atau tugasnya. ${ }^{3}$

Ada yang menarik dari ketentuan pasal 12 C. Menurut ketentuan Pasal 12C dengan melaporkan gratifikasi yang diterimanya kepada Komisi Pemberantasan Tindak Pidana Korupsi, maka akan meniadakan pidana pada Pasal 12B. Apakah ketentuan mengenai melaporkan penerimaan gratifikasi ini merupakan alasan penghapus pidana? Kiranya tidak, karena alasan peniadaan pidana dalam doktrin hukum terdiri atas alasan pemaaf dan alasan pembenar yang terbentuk oleh hal-hal yang sudah ada dan berlaku pada saat perbuatan dilakukan.

Bahkan perbuatan tersebut merupakan bagian dari perbuatan yang dilakukan pembuat dan atau bagian dari keadaan batin si pembuat, yang memang harus sudah ada/terdapat pada saat perbuatan dilakukan, dan bukan sesudah perbuatan dilakukan. Sedangkan tindakan pegawai negeri penerima gratifikasi "melaporkan penerimaan gratifikasi" kepada KPTPK adalah sesudah perbuatan terjadi, atau jauh setelah terjadinya perbuatan, bisa jadi pada ke 30 (tiga puluh) hari kerja. Oleh karena itu dari sudut ini tindakan melaporkan penerimaan gratifikasi tidak dapat dianggap sebagai alasan peniadaan pidana ${ }^{4}$.

Syarat pelaporan bagi pegawai negeri yang menerima gratifikasi, ditujukan pada 3 (tiga) hal, ialah: pertama, untuk tidak mempidana pegawai negeri yang secara sukarela melaporkan tentang penerimaan gratifikasi. Pelaporan dapat dinilai sebagai suatu kesadaran bagi pegawai negeri untuk berbuat jujur, menegakkan moral dan menjujung tinggi derajat dan martabat serta sumpah jabatan oleh pegawai negeri atau penyelenggara negara sebagai pelaksana pelayanan publik. Kedua, bertujuan pendidikan moral bagi pegawai negeri atau penyelenggara negara. Dalam waktu 30 hari kerja, adalah waktu yang cukup bagi pegawai negeri untuk merenungkan dengan hati, memikirkan dengan akal tentang haramnya pemberian gratifikasi.

ketiga, ditujukan untuk menentukan apakah penerimaan gratifikasi menjadi milik negara atau milik pegawai negeri yang menerima gratifikasi (pasal $12 \mathrm{C}$ ayat $(3)^{5}$.

\section{a.1.2. Pembuktian Terbalik Mengenai Harta Benda yang Belum Didakwakan (Pasal 38B jo 37) \\ Norma Pasal 38B ayat (1) dapat dijelaskan} sebagai berikut:

1. Norma ayat (1) adalah dasar hukum sistem beban pembuktian terbalik dalam hal objek pembuktian harta benda terdakwa yang belum didakwakan, tapi diduga berasal dari TPK.

2. Pembuktian mengenai harta benda yang belum didakwakan sebagai bukan hasil korupsi adalah berlaku dalam hal tindak pidana yang didakwakan dalam perkara pokok, adalah TPK Pasal: 2, 3, 4, 14, 15 UUTPK $^{6}$ Hanya TPK suap menerima gratifikasi Pasal 12B saja yang tidak disebut dalam Pasal 38B ayat (1).

Walaupun Pasal 37 merupakan dasar hukum pembuktian terbalik. Namun khusus mengenai objek harta benda terdakwa yang belum didakwakan (termasuk juga yang didakwakan dalam surat dakwaan), tidaklah dapat menggunakan Pasal 37. Karena Pasal 37 adalah khusus diperuntukkan bagi pembuktian terdakwa mengenai dakwaan tindak pidana (khususnya suap menerima gratifikasi Rp 10 juta atau lebih), dan bukan dakwaan mengenai harta benda. Maka keberhasilan terdakwa membuktikan tentang kekayaannya itu bersumber pada pendapatan yang halal, tidaklah harus ia dibebaskan dalam dakwaan perkara pokok melakukan TPK, melainkan sekedar menyatakan harta benda yang belum didakwakan tersebut bukan hasil korupsi, dan menolak tuntutan JPU untuk menjatuhkan pidana perampasan harta benda tersebut saja. ${ }^{?}$

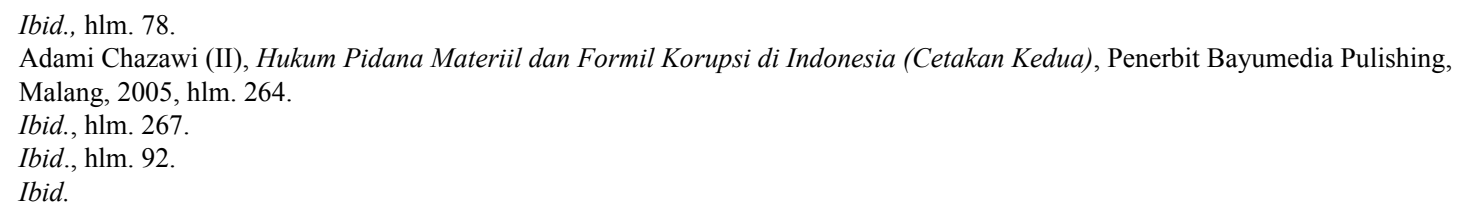




\section{a.2. Sistem Semi Terbalik dan Biasa}

Dasar hukum sistem semi terbalik ada pada Pasal 37A ayat (3) UUTPK.

TPK selain suap menerima gratifikasi penerapan pembuktikan tentang harta benda terdakwa (yang telah didakwakan) dilakukan dengan cara yang dirumuskan dalam Pasal 37A. Tentang beban pembuktikan kepada siapa dan bagaimana cara membuktikan menurut ketentuan pasal ini dapat disebut dengan sistem pembuktian semi terbalik. Karena hasil pembuktian terbalik mengenai harta benda menurut ketentuan ini, dapat digunakan oleh jaksa untuk memperkuat alat buktinya, yakni bila pembuktiannya itu tidak berhasil membuktikan keseimbangan antara hartanya dengan sumber pendapatannya.

Contohnya, kelebihan kekayaan (diluar) dari kekayaan yang sebenarnya yang diperoleh dari sumber kekayaan atau sumber tambahan kekayaan yang sah. Pada kenyataannya kekayaan yang demikian ini adalah kekayaan yang tidak jelas cara perolehannya atau tidak jelas asal usulnya. Sebagai contoh wajarkah seorang Pegawai Negeri Sipil (PNS) golongan III A yang gajinya 2 juta/ bulan mempunyai mobil Alpard dan rumah mewah di pondok Indah.

Jika menggunakan sistem biasa seperti pada KUHAP, dalam hal untuk membuktikan tindak pidana beban pembuktian sepenuhnya pada JPU. Sedangkan terdakwa tidak wajib, dalam arti pasif. Namun demikian dalam sistem akusator (accusatoir), demi hukum terdakwa mempunyai hak untuk menyangkal dakwaan dan membuktikan sebaliknya. ${ }^{8}$ Dalam hukum pidana korupsi, sistem pembuktian TPK suap menerima gratifikasi yang nilai objeknya kurang dari Rp 10 juta (Pasal 12B ayat huruf b) menggunakan beban pembuktian biasa, yakni pada jaksa.

Apabila dilihat dari sudut pembebanan pembuktian Pasal 37A, maka dalam hal pembuktian kekayaan terdakwa ternyata seimbang dengan sumber pendapatannya, dimana JPU juga tetap wajib membuktikan tentang tindak pidana yang didakwakannya, maka dapat disebut dengan sistem semi terbalik. Karena dibebani kewajiban membuktikan terbalik secara berimbang, maka dapat juga disebut dengan sistem berimbang terbalik. Mengenai alat bukti dan syarat pembuk- tiannya baik oleh terdakwa atau JPU mengikuti ketentuan dalam KUHAP, karena mengenai hal ini tidak ada ketentuan khusus dalam UUTPK.

Bagi terdakwa pembuktian tentang kekayaan terdakwa yang seimbang dengan sumber pendapatannya diperlukan, agar harta benda tersebut tidak dijatuhi pidana perampasan barang. Bagi jaksa baru menjadi penting, apabila terdakwa tidak berhasil membuktikan kekayaannya sesuai dengan sumber pendapatannya. Dalam kenyataannya harta yang demikian ini adalah harta yang tidak jelas cara perolehannya atau asal usulnya. Keadaan terdakwa tidak dapat membuktikan sumber kekayaannya yang sah tersebut digunakan untuk memperkuat alat bukti yang sudah ada bahwa terdakwa melakukan korupsi (Pasal 37 ayat 2).

Tidak semua keadaan terdakwa yang tidak berhasil membuktikan tentang sahnya sumber kekayaannya dapat menguntungkan JPU. Baru dapat digunakan memperkuat alat bukti yang sudah ada, apabila keadaan terdakwa tidak berhasil membuktikan sumber kekayaannya itu memenuhi 2 syarat, yaitu:

1. Pertama, JPU telah menggunakan minimal 2 alat bukti yang sah, dan

2. Kedua, ketidak berhasilan terdakwa membuktikan keseimbangan antara kekayaan dengan sumber pendapatannya ada hubungan dengan berhasilnya JPU membuktikan perolehan kekayaan dari tindak pidana yang didakwakan. Hubungan ini adalah berupa kekayaan yang tidak dapat dibuktikan sumbernya yang halal oleh terdakwa tadi bersesuaian dengan hasil pembuktian JPU tentang tindak pidana yang didakwakan menurut sifat dan kenyataannya menghasilkan suatu kekayaan.

JPU memperkuat alat bukti yang sudah ada sebagaimana dimaksud Pasal 37A ayat (2), boleh dengan cara menggunakan alat bukti petunjuk. Dan didukung pula oleh Ketentuan Pasal 188 ayat (1) KUHAP.

Oleh karena alat bukti petunjuk ini adalah berupa pemikiran atau pendapat hakim yang dibentuk dari hubungan atau persesuaian alat bukti yang ada dan dipergunakan dalam sidang, maka sifat subjektifitas hakim lebih dominan. Oleh 
karena itu Pasal 188 ayat (3) mengingatkan hakim agar dalam menilai kekuatan alat bukti petunjuk dalam setiap keadaan tertentu harus dilakukan dengan arif dan bijaksana, setelah hakim memeriksa dengan cermat dan seksama yang didasarkan hati nuraninya9 .

Keadaan terdakwa yang tidak berhasil membuktikan dalam konteks sistem semi terbalik dinilai sebagai keterangan terdakwa yang memberatkan dan digunakan sebagai bahan membentuk alat bukti petunjuk. Karena hukum korupsi tidak mengatur secara khusus syarat-syarat bukti petunjuk harus berdasarkan KUHAP (UU korupsi hanya memperluas bahan untuk membentuk alat bukti petunjuk). Untuk dapatnya dibentuk alat bukti petunjuk JPU perlu menggunakan minimal 2 alat bukti termasuk alat bukti informasi dan atau dokumen sebagaimana dimaksud Pasal 26A.

Disinilah letak peran JPU dalam sistem pembuktian semi terbalik, khususnya kalimat dalam Pasal 37A, “.......digunakan memperkuat bukti yang sudah ada bahwa terdakwa telah melakukan TPK” (ayat 2) dan kalimat: “...... sehingga penuntut umum tetap berkewajiban untuk membuktikannya" (ayat 3).

Sedangkan sistem beban pembuktian biasa, berpijak pada asas tiada pidana tanpa kesalahan (presumtion of innocence) dalam hukum acara pidana yang diatur dalam Pasal 8 Ayat (1) UU Nomor 48/2009 tentang Kekuasaan Kehakiman dan penjelasan umum angka 3 huruf c KUHAP.

Sebagian orang berpendapat bahwa asas presumtion of innocence hanya berlaku di depan sidang pengadilan. Pendapat itu salah dan menyesatkan. Dalam rumusan norma Pasal 8 (1) UU Nomor 48/2009 sangat jelas, bahwa presumtion of innocence berlaku sejak orang disangka, ditangkap, ditahan, dituntut sampai di sidang pengadilan. Orang yang berpendapat salah tadi hanya melihat sepotong dari rumusan normanya.

Oleh karena terdakwa dianggap tidak bersalah, maka jika terdakwa didakwa oleh Jaksa, maka Jaksa yang dibebani untuk membuktikan apa yang didakwakan itu benar. Setiap orang dianggap tidak bersalah sampai kesalahannya itu dibuktikan dengan suatu putusan pengadilan yang telah mempunyai kekuatan hukum tetap. ${ }^{10}$

9 Adami Chazawi (I), Op. Cit., hlm. 49

10 Ibid., hlm. 12.
Dalam sistem ini, terdakwa atau penasihat hukum tidak dibebani kewajiban untuk membuktikan dirinya tidak bersalah melakukan tindak pidana yang didakwakan. Terdakwa dan atau penasihat hukum justru mempunyai hak untuk membuktikan sebaliknya, atau hak menolak dengan membuktikan sebaliknya.

Mengenai beban pembuktian tindak pidana yang didakwakan dalam hukum pembuktian korupsi selalu diletakkan pada JPU. Kecuali terhadap pembuktian TPK menerima suap gratifikasi yang nilainya Rp 10 juta atau lebih, yang dibebankan pada terdakwa. Dari sudut pembuktian mengenai objek tindak pidana yang didakwakan, maka sistem beban pembuktian korupsi dapat disebut sistem beban pembuktian terbatas. Hanya sebagian kecil (satu) saja tindak pidana yang menggunakan beban pembuktian terbalik murni, yakni hanya objek tindak pidana menerima suap gratifikasi dalam Pasal 12 B saja. Selebihnya tidak, menggunakan sistem beban pembuktian biasa.

Semua prosedur pembuktian semi terbalik dan yang di dalamnya terdapat cara sistem biasa sebagaimana diuraikan sebelumnya, tiada lain diarahkan oleh JPU pada tujuan akhir adalah untuk membuktikan tentang telah terjadinya TPK yang didakwakan dan terdakwa bersalah melakukan TPK tersebut.

\section{b. Permasalahan Beban Pembuktian Terbalik TPK}

Jenis korupsi menerima suap gratifikasi Pasal 12B adalah suatu jenis tindak pidana suap pasif. Cara merumuskan TPK suap gratifikasi ini tidak lazim. Dalam rumusannya nampak seolaholah subjek hukumnya adalah si penyuap, tetapi sesungguhnya bukan. Alasannya ialah oleh Pasal 12B tidak diberikan ancaman pidana pada pemberi suap gratifikasi. Justru yang diancam pidana pada ayat (2) adalah pegawai negeri atau penyelenggara negara yang menerima gratifikasi. Oleh karena itu rumusan suap gratifikasi bukan ditujukan pada subjek hukum pemberi suap, tetapi ditujukan pada penerima suap/menerima gratifikasi. Ancaman pidananya jelas ditujukan pada pegawai negeri.

Pasal 12B ayat (1) merumuskan secara sumir tentang sistem pembebanan pembuktian terbalik. 
Ketentuan pasal ini juga menerangkan hal syarat mengenai jumlah (rupiah) menerima suap gratifikasi yang beban pembuktiannya pada terdakwa, sedangkan selebihnya tidak cukup membuat terang setidak-tidaknya tentang:

- Bagaimana prosedur atau cara terdakwa dalam membuktikan?

- Apa syarat-syarat (standar) yang harus ada untuk dapat dinyatakan terdakwa berhasil membuktikan dan tidak berhasil membuktikan? ${ }^{11}$

Apabila tidak diatur lain, pembuktian harus sesuai dengan KUHAP. Artinya masalah seperti di atas, sepanjang tidak jelas dalam UU TPK maka kembali pada KUHAP. Apabila dalam hubungannya dengan KUHAP belum terang juga, maka diserahkan pada praktik hukum melalui penemuan hukum.

Unsur sistem pembuktian, ialah alat-alat bukti yang boleh digunakan dan caranya membuktikan serta standard yang harus dipenuhi untuk menyatakan terbukti atau tidaknya mengenai objek apa yang dibuktikan. Alat-alat buktinya jelas ialah dengan menggunakan alat-alat bukti Pasal 183 ayat (1) KUHAP jo Pasal 26A UUTPK

Mengenai objek harta benda yang tidak didakwakan dalam surat dakwaan tidak menyangkut langsung dengan unsur-unsur tindak pidana dakwaan. Sistem terbalik untuk objek harta benda terdakwa yang tidak disebut dalam dakwaan, bukan untuk membuktikan kesalahan terdakwa melakukan TPK yang didakwakan, melainkan apabila terdakwa tidak berhasil membuktikan, untuk menjatuhkan pidana perampasan barang atau sebaliknya. Pada hal untuk menjatuhkan pidana apapun jenisnya, syaratnya ialah harus dibuktikan dahulu tentang kesalahan terdakwa melakukan tindak pidana yang didakwakan. Membuktikan tindak pidana adalah membuktikan unsur-unsurnya. Membuktikan kesalahan terdakwa adalah membuktikan adanya hubungan batin (subjektif) terdakwa dengan terwujudnya tindak pidana yang didakwakan. Dalam hukum korupsi, untuk membuktikan unsur-unsur TPK justru tidak menggunakan sistem beban pembuktian terbalik.
Oleh karena itu pada tahap akhir pembuktian terhadap dua objek yang berbeda (yang satu objek kekayaan yakni sumbernya dan yang lain mengenai unsur-unsur tindak pidananya) dengan sistem beban pembuktian yang berbeda. Dengan begitu bisa saja menghasilkan sesuatu yang berbeda.

Apabila perbedaan hasil pembuktian, misalnya terdakwa berhasil membuktikan sumber kekayaanya (yang belum didakwakan) adalah sumber yang halal, tidak ada masalah meskipun perkara pokoknya terbukti dan terdakwa dipidana karena perbuatannya itu. Sebaliknya akan menjadi masalah hukum, apabila disatu pihak terdakwa tidak berhasil membuktikan sumber kekayaan misalnya sebuah deposito 12 miliar rupiah, tetapi dilain pihak JPU juga tidak berhasil membuktikan misalnya dakwaan menggelapkan uang negara (Pasal 8 UUTPK) ${ }^{12}$. Perbedaan hasil pembuktian tersebut menimbulkan akibat hukum yang ganjil. Deposito Rp 12 miliar bisa dirampas untuk negara, tetapi dibebaskan dari perkara pokok Pasal 8 karena tidak terbukti.

Keganjilan itu bisa terjadi dikarenakan pembuktian Pasal 8 adalah membuktikan semua unsur-unsurnya. Sedangkan membuktikan harta benda yang belum didakwakan adalah tentang sumber (yang halal) dari mana diperoleh deposito Rp 12 miliar tersebut. Walaupun dengan adanya ketentuan Pasal 38B ayat $(6)^{13}$ hal perampasan barang tidak boleh dilakukan. Namun masalah tersebut tidak bisa dijawab dengan hanya tidak menjatuhkan pidana perampasan barang. Karena deposito itu tidak jelas asal usulnya, tapi negara tidak bisa berbuat apa-apa. Sebenarnya kejadian seperti ini dapat dihindari, apabila JPU mendakwakan TPK yang sesuai dengan perolehan kekayaan terdakwa yang tidak jelas sumbernya tersebut.

Jika didakwa TPK menerima suap gratifikasi, maka objek dan cara pembuktian ialah:

1. Pertama, bahwa tidak ada gratifikasi yang diterima, atau bukan terdakwa yang menerima gratifikasi tersebut;

2. Kedua, bahwa jika terbukti ada sesuatu penerimaan (gratifikasi), maka terdakwa

11 Adami Chazawi (I), Op. Cit., hlm. 121.

12 Pasal 8 UUTPK, mengenai penggelapan uang/surat berharga yang dilakukan oleh PNS karena jabatannya.

13 Apabila terdakwa dibebaskan atau dinyatakan lepas dari segala tuntutan hukum dari perkara pokok, maka tuntutan perampasan harta benda sebagaimana dimaksud dalam ayat (1) dan ayat (2) harus ditolak oleh hakim. 
membuktikan bahwa penerimaan itu bukan berhubungan dengan jabatannya dan atau tidak berlawanan dengan kewajiban atau tugasnya. Jadi mengacu pada unsur-unsurnya, tetapi kebalikan (negatif) yakni tidak ada unsurunsur TPK tersebut;

3. Ketiga ia telah melaporkan pada KPK tentang penerimaan itu dalam waktu 30 hari kerja sejak menerimanya. Menurut Pasal 37 ayat (2) bila terdakwa dapat membuktikan seperti itu, maka pembuktian tersebut dipergunakan oleh pengadilan sebagai dasar untuk menyatakan bahwa dakwaan tidak terbukti. Oleh karena pembuktian (negatif) oleh terdakwa ini mengenai objek TPK (menerima suap gratifikasi) tentu harus diikuti dengan diktum pembebasan terdakwa. Disini letak sistem terbalik justru menguntungkan terdakwa. Karena hakim tidak perlu mempertimbangkan hasil pembuktian JPU. ${ }^{14}$

Meskipun objek pembuktian sistem terbalik sangat terbatas, untuk memaksimalkan penerapannya, diperlukan JPU mendakwakan Pasal 12B tentang TPK menerima suap gratifikasi. Dalam hal perkara yang tepat bagi JPU untuk mendakwakan Pasal 12B sehingga pembuktiannya dapat menggunakan sistem terbalik, adalah dalam perkara korupsi suap pasif yang nilainya besar yang dilakukan dalam waktu yang lama dan sukar pembuktiannya dengan sistem biasa. Misalnya Rekening gendut di kepolisian yang sampai kini tidak jelas hasil penyelidikan atau penyidikannya atau rekening gendut para Pegawai Negeri Sipil (PNS) pegawai dirjen Pajak yang tidak jelas asalusulnya.

Memang tidak mudah membuktikan satusatu penerimaan suap dari tiap-tiap pengusaha atau para pencari keadilan serta kapan saat penerimaan itu terjadi. Hanya tepat untuk kasuskasus semacam itu. Sesungguhnya sistem beban pembuktian terbalik TPK bertumpu pada konsep memudahkan pembuktian bagi TPK yang sukar pembuktiannya dengan sistem biasa. Demikianlah itulah maksud pembentuk Undang-undang memasukkan sistem pembebanan pembuktian terbalik bagi TPK suap menerima gratifikasi dalam UU TPK.

\section{Kesimpulan}

Dilihat dari siapa yang dibebani membuktikan serta objek pembuktiannya, dapat dibedakan antara 3 sistem, ialah: (1) sistem terbalik, (2) sistem semi terbalik dan (3) sistem biasa. Mengenai sistem beban pembuktian terbalik dalam UUTPK, terbatas pada dua objek saja. Objek tindak pidana menerima suap gratifikasi yang nilainya $\mathrm{Rp} 10$ juta atau lebih (Pasal 12B) dan objek mengenai harta benda terdakwa yang tidak/belum disebut dalam surat dakwaan (Pasal 38B).

Sistem semi terbalik berlaku dalam hal pembuktian tentang harta benda terdakwa yang telah didakwakan, khususnya bagi terdakwa membuktikan tentang kekayaannya seimbang dengan sumber pendapatannya. Sebaliknya keadaan tidak berhasilnya terdakwa membuktikan kekayaan itu didapat dari sumber yang halal, dipergunakan JPU untuk memperkuat alat bukti yang membuktikan unsur-unsur TPK yang didakwakan. Sedangkan sistem biasa (beban pembuktian pada JPU) berlaku pada TPK suap menerima gratifikasi yang nilainya kurang dari Rp 10 juta dan semua TPK selain suap menerima gratifikasi yang nilainya $\mathrm{Rp} 10$ juta atau lebih. Dalam memberantas korupsi, sistem terbalik tidak banyak manfaatnya. Bermanfaat karena objek pembuktiannya sangat terbatas, yakni pada TPK suap menerima gratifikasi yang nilainya $\mathrm{Rp} 10$ juta atau lebih saja.

Sistem terbalik, disatu pihak memang memudahkan pembuktian dalam hal didakwa suap menerima gratifikasi. Memudahkan artinya lebih berpihak dan menguntungkan JPU. Tetapi sebaliknya sistem terbalik dapat menjadi sangat menguntungkan terdakwa dan merugikan JPU. Hal ini bisa terjadi disebabkan karena dalam sistem terbalik JPU pasif dalam pembuktian. Sistem terbalik harus digunakan dalam kasuskasus besar dengan syarat-syarat: (1) pegawai negeri atau penyelenggara negara diduga telah menerima suap terutama dari banyak pihak, dalam waktu yang lama dan berkali-kali, (2) penerimaan suap tersebut sukar dibuktikan misalnya kapan saat menerima suap, dari siapa saja penyuapnya dan berapa masing-masing jumlahnya, (3) yang menimbulkan atau menjadikan kekayaannya berlimpah ruah, (4) yang tidak seimbang dengan gaji atau sumber pendapatan lainnya yang sah. 


\section{DAFTAR PUSTAKA}

\section{Buku}

Adami Chazawi (I), 2011, Hukum Pembuktian Tindak Pidana Korupsi, Penerbit Bayumedia Publishing, Malang.

(II), 2005, Hukum Pidana Materiil dan Formil Korupsi di Indonesia (Cetakan Kedua), Penerbit Bayumedia Pulishing, Malang.

Andi Hamzah, 2011, Hukum Acara Pidana Indonesia, Penerbit Sinar Grafika, Jakarta.

\section{Peraturan Perundang-undangan}

Undang-undang Nomor 8 Tahun 1981 tentang kitab Undang-undang Hukum Acara Pidana

Undang-undang Nomor 31 Tahun 1999 tentang pemberantasan tindak pidana korupsi

Undang-undang Nomor 20 Tahun 2001 tentang perubahan atas UU No. 31 tahun 1999 Tentang pemberantasan tindak pidana korupsi 